\title{
The genus Ectadia (Orthoptera: Phaneropteridae: Phaneropterinae) in East Asia: description of a new species, comparison of its complex song and duetting behavior with that of $E$. fulva and notes on the biology of $E$. fulva
}

\author{
Klaus-Gerhard Heller', Sigfrid Ingrisch'², Elżbieta Warchatowska-Śliwa33, Chunxiang Liư
}

1 Grillenstieg 18, D-39120 Magdeburg, Germany.

2 Zoological Research Museum Alexander Koenig, Adenauerallee 160, D-53113 Bonn, Germany.

3 Institute of Systematics and Evolution of Animals, Polish Academy of Sciences, Kraków, Poland.

4 Key Laboratory of Zoological Systematics and Evolution, Institute of Zoology, Chinese Academy of Sciences, Beijing 100101, China.

Corresponding author: K.-G. Heller (heller.volleth@t-online.de)

Academic editor: Juliana Chamorro | Received 24 February 2017 | Accepted 2 April 2017 | Published 28 June 2017

http://zoobank.org/0397BEAD-8CAC-4353-B60B-09B9BCA2FC0E

Citation: Heller K-G, Ingrisch S, Warchałowska-Śliwa E, Liu C (2017) The genus Ectadia (Orthoptera: Phaneropteridae: Phaneropterinae) in East Asia: description of a new species, comparison of its complex song and duetting behavior with that of $E$. fulva and notes on the biology of $E$. fulva. Journal of Orthoptera Research 26(1): 39-51. https://doi.org/10.3897/jor.26.14548

\begin{abstract}
The genus Ectadia is an East Asian genus of the tribe Elimaeini (Phaneropterinae) and is known for the complex stridulatory files of its members. The calling song was so far known from only one species, the relatively widespread Ectadia fulva. Here a new species from Yunnan, China, is described, which is morphologically similar to E. fulva except for the stridulatory file. In this character E. fulva deviates strongly from the new species and from all other Ectadia species by its high tooth number. The long lasting song (duration 30 to 60 seconds at $25^{\circ} \mathrm{C}$ ) of the new species is very complex and differs widely from the much shorter song of $E$. fulva. Its spectral composition changes during stridulation. In the new species the females respond acoustically during gaps in the final part of the male song, whereas in E. fulva they answer typically after the male song. During mating Ectadia fulva males transfer small spermatophores without spermatophylax. All of its six nymphal stages are cryptically colored. In karyotype the new species being the first studied Ectadia species is similar to the related genera Elimaea and Ducetia (all 2n=29 chromosomes in the male).
\end{abstract}

\section{Key words}

calling song, stridulatory file, male-female-duet, carrier frequency, Yunnan

\section{Introduction}

In nearly all species of the subfamily Phaneropterinae, males and females communicate by duetting to find a mate (see Heller et al. 2015 for a review). The male seems always to initiate the duet, but the structure of its songs varies widely. Many species have simple songs; however, there are several genera with quite complicated male calling song patterns. The genus Ectadia Brunner von Wattenwyl, 1878 belongs to the second group. Ectadia is a mainly (South) East Asian genus with at present eight species. Males of those species do not have titillators in their genitalic organs and the cerci are quite similar, but they differ widely in their stridulatory organs that are known from all species except of the Indian $E$. pilosa (see Liu et al. 2004, Gorochov 2009).
Six species are endemic to South China (Yunnan) and northern Vietnam (Liu et al. 2004, Gorochov 2009), one species (E. fulva Brunner von Wattenwyl, 1893) is more widespread in South East Asia (Myanmar, Thailand, Vietnam, China: Yunnan, Guanxi, Fujian; Liu et al. 2004, Kang et al. 2014; Fig. 1), but the type species of the genus (E. pilosa Brunner von Wattenwyl, 1878) is only known from one male collected in Kashmir (India). Thus clearly the centre of its distribution is the Chinese province Yunnan where five species have been found. It may not be so surprising to find a high number of species in this relatively small area, since Yunnan is one of the global biodiversity hotspots, well known for plant diversity (Li et al. 2015, Tang 2015), although not yet so much for insects (but see e.g. Morgan et al. 2011). Therefore, when we heard an unknown calling song of an Ectadia species during a joint excursion (CXL and KGH) in Yunnan, we expected to find one of these species. Surprisingly, however, our species differed morphologically from all other known species. Its song was even more complicated (some details mentioned already in Heller et al. 2015 as Ectadia sp.) than that of E. fulva, the morphologically most similar species and the only one with known song (Ingrisch 1998, Heller et al. 2015).

In this paper we will describe the species as new and as the sixth member of the genus in Yunnan. In addition, we will present some more data of song and behaviour of E. fulva in comparison.

\section{Material and methods}

Measurements. - Total body length, lateral aspect, refers to the midline length of the insect from fastigium verticis to tip of abdomen including the subgenital plate. In females, the ovipositor is not included in the measurement of the body length. Measurements of ovipositors are taken laterally from tip to base not regarding the curvature.

To obtain the mass data, living animals and spermatophores were weighed to the nearest mg (balance Mettler PM 640).

Depositories.-IZCAS Insect Collection of Institute of Zoology, Chinese Academy of Sciences, Beijing, China. CH Collectio Heller. 
Acoustics. - The male calling song of E. diuturna sp. n. was recorded in the field and in the laboratory using a digital bat detector (Pettersson D1000X) with sampling rates between 100 and 300 $\mathrm{kHz}$. Duets were recorded in stereo using a Sony ECM-121 microphone (frequency response relatively flat up to $30 \mathrm{kHz}$ according to own tests) and an Uher M645 microphone connected to a personal computer through an external soundcard (Transit USB, "M-Audio"; 64-kHz sampling rate). The recordings of Ectadia fulva were made in the laboratory with a Racal store 4-D tape recorder using microphones Brüel and Kjær 4133 and 4135 (frequency response flat up to 40 and $70 \mathrm{kHz}$ respectively)(KGH) and with Kenwood KX880HX and Sony D7 tape recorders using Sennheiser BlackFire541, Sennheiser stereo and AIWA CM-S1 stereo microphones (SI) and digitised years later.

The stridulatory movements of Ectadia fulva were registered by an opto-electronic device (Helversen and Elsner 1977, modified as in Heller 1988).

Song measurements and spectrograms were obtained using Amadeus II and Amadeus Pro (Martin Hairer; http://www.hairersoft.com). Oscillograms of the songs were prepared using Turbolab (Bressner Technology, Germany). All recordings were made at temperatures between 18 and $25^{\circ} \mathrm{C}$. The singers were caged in plastic tubes or gauze cages with microphone fixed or hand-held at distances between 5 (duet) and $80 \mathrm{~cm}$.

For measurements of the stridulatory files, replicas were made using the cellulose nitrate technique described by Ragge (1969). For tooth spacing, each point in the figures represents the mean of ten consecutive intervals.

Acoustical terminology. - Tettigonioids produce their songs by repeated opening and closing movements of their tegmina. The sound resulting during one cycle of movements is called a syllable, often separatable in opening and closing hemisyllable (Ragge and Reynolds 1998). While most species open and close their wings with a more or less uniform amplitude, some species use more complicated patterns, where the term syllable is difficult to apply, if the movement pattern can be reconstructed at all. For the description of the songs of Ectadia we will use the terms micro- and macrosyllables. Movement recordings in E. fulva have demonstrated (Heller et al. 2015), that the short impulse (see below) groups (microsyllables) are produced during contact of the large file teeth, the longer lasting impulse groups (macrosyllables) during contact of the small file teeth with the scraper. For the new species we assume the same basic pattern. Syllable duration: time period measured from the first impulse to the last; syllable period: time period measured from the first impulse to the first impulse of the next syllable; impulse: a simple, undivided, transient train of sound waves (here: the damped sound impulse arising as the effect of one tooth of the stridulatory file).

In Ectadia (as in other species), after some time the same or a similar pattern of syllables and pauses is repeated. This grouping, often separated from the next by a silent interval, is called a song unit.

Chromosomal analysis. - The sample of a male paratype of Ectadia diuturna sp. n. (CH7661) was used for cytotaxonomic analyses. Gastric caeca were incubated in a hypotonic solution $(0.9 \%$ sodium citrate), fixed in ethanol - acetic acid (3:1, v/v) and squashed in $45 \%$ acetic acid. Cover slips were removed by the dry ice procedure and then preparations were air dried. Constitutive heterochromatin was revealed by the C-banding technique as described by Sumner (1972). Fluorescence in situ hybridization (FISH) with ribosomal 18S rDNA (rDNA) genes was performed exactly as described in Grzywacz et al. (2011).

\section{Results}

Ectadia diuturna Heller \& Liu, sp. n.

http://lsid.speciesfile.org/urn:lsid:Orthoptera.speciesfile.org:-

TaxonName:498339

http://zoobank.org/F95FF011-8A43-4959-AB8D-692D5968D562

Figs 3-9 morphology, Figs 10-13 song, Fig. 14 chromosomes

Ectadia sp. in Heller et al. 2015, p. 3, 6. fig. 5

Material examined.- Holotype male, China, Yunnan, Honghe, Pingbian, Daweishan Forest Reserve, $22^{\circ} 56.55^{\prime} \mathrm{N}, 103^{\circ} 41.43^{\prime} \mathrm{E}$, 1700-2100 m a.s.l., 15-17 viii 2013, leg. Liu Chunxiang, \#CH7660, in ethanol. Depository IZCAS.

Paratypes 11 males (\#CH7659, 61-62), 6 females (\#CH7663-5), dried/in ethanol, same data as holotype, all in IZCAS except \#CH7659, 61, 64 (in $\mathrm{CH}$ ). In addition sound recordings of two males, not collected.

Diagnosis. - Differs from all species of the genus in proportions of anal (1/3) and basal (2/3) part of the stridulatory file and number (about 100; Table 1) and distribution of teeth on the stridulatory file (Figs 2, 3). From E. apicalis, which has a similar stridulatory file, it differs by larger size and the hind wings being clearly longer than the tegmina while slightly shorter in E. apicalis. In general habitus it is most similar to E. fulva, but has a much lower number of teeth on stridulatory file (see Fig. 3) and narrower tegmina (Fig. 4).

Description. - Male. General habitus see Fig. 5.

Fastigium verticis narrower than first segment of antennae, sulcate dorsally, not contacting fastigium frontis. Complex eyes approximately round. Pronotum with disc nearly flat, only last quarter elevated; anterior margin slightly concave, posterior margin truncate with small notch in middle; medial carina inconspicuous; transverse sulcus V-shaped; lateral carina weakly developed; lateral lobe of pronotum much longer than high, anterior margin straight, posterior margin obtuse-rounded, ventral margin oblique downward posteriorly, humeral sinus present but inconspicuous.

Prothoracic spiracle large, but mostly covered by a posterior extension of paranotum.

Tegmen shorter than hind wing, posteriorly with long parallel part (Figs 4A, 5A); venation see Fig. 4. Mirror in stridulatory area of right tegmen with a more or less circular deepening, similar to that in E. fulva (Fig. 6). The vein demarcating the distal end of the stridulatory area curved smoothly, not with an edge as in $E$. fulva (Fig. 6). Stridulatory file comparatively straight but slightly thinner in middle, with circa 90 densely spaced fine teeth in basal area and about 10 widely spaced large teeth in distal (=apical or anal) area (Fig. 3). Fore coxae without spine, fore tibiae dorsally sulcate and spinuliferous. All femora ventrally spinulose; mid and hind femur with 5-6 spines on outer ventral margins; hind tibiae with many spines on both dorsal margins. Tenth abdominal tergite prolonged backwards, hind margin emarginate; cerci stoutest at base, basal quarter sharply acuminated, then first slightly widening, later gradually narrowed till apex, dorsoventrally flattened; subgenital plate split for almost apical two thirds, up-curved (Figs 7, 8). Internal genitalia membranous, no sclerotized titillator.

Color.- Body and tegmina green, parts of legs, dorsal side of pronotum and dorsal field of tegmina brown, tegmina with some small brown dots (Figs 4, 5). 


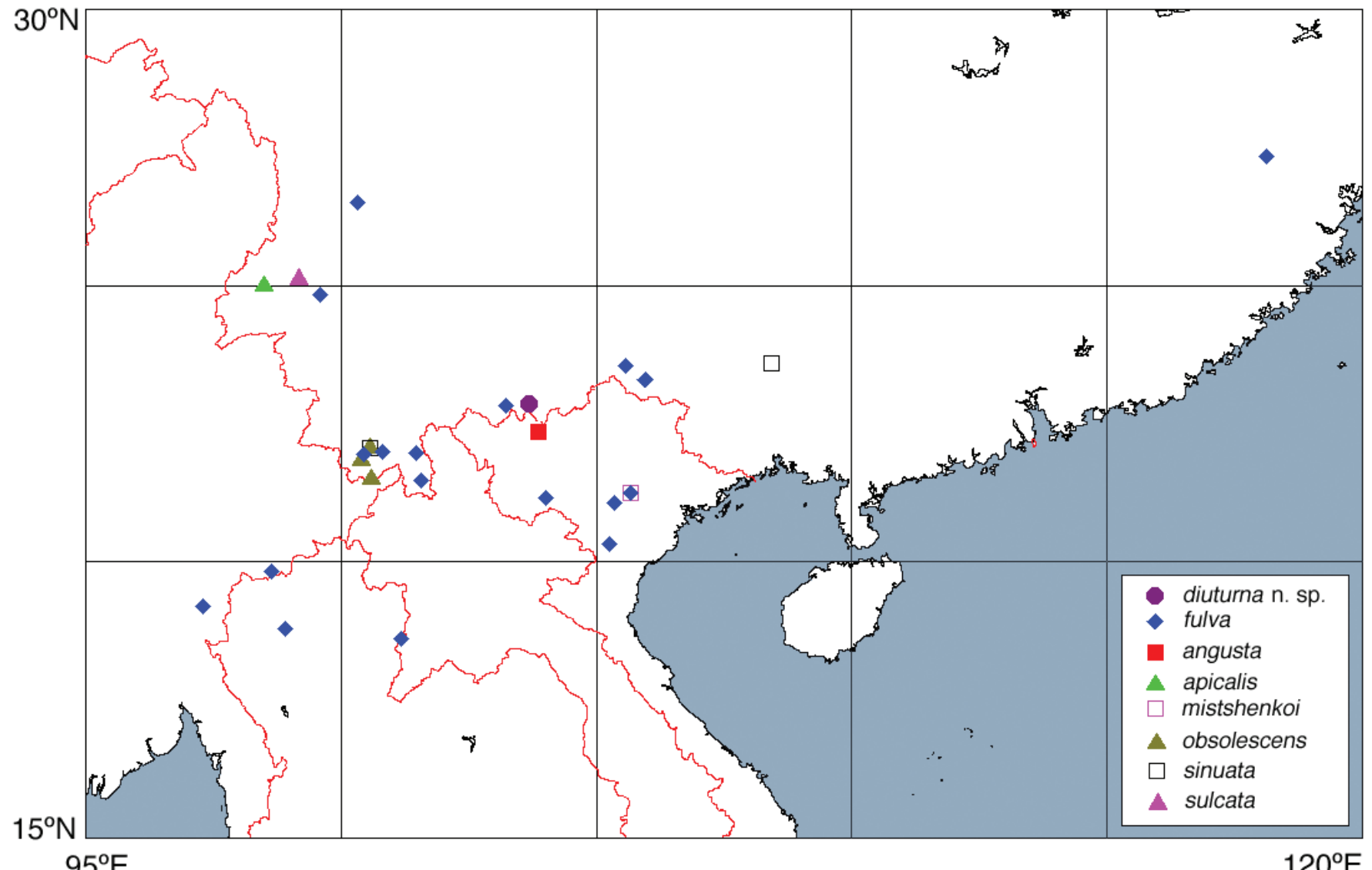

Figure 1. Distribution map of genus Ectadia (except E. pilosa, Kashmir; based on data of Brunner von Wattenwyl 1893, Liu et al. 2004, Gorochov 2009, Bey-Bienko 1962, Ingrisch 1998, Bai and Shi 2014).

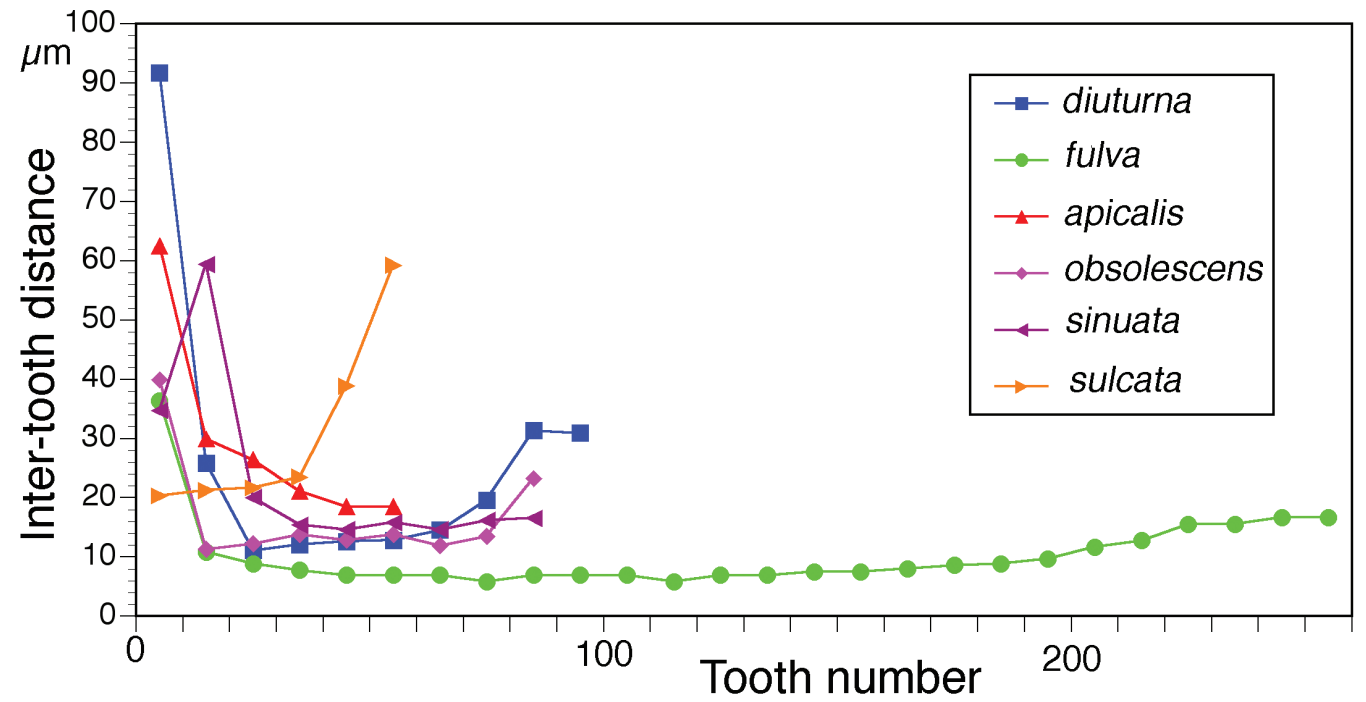

Figure 2. Inter-tooth spacing in male stridulatory files of Ectadia species.

Female. - Mostly similar to male except abdominal apex and tegmina (stridulatory organs).

Pronotom with disc nearly flat; ventral and dorsal edge of paranotum parallel.
Right tegmen at posterior edge in basal part with about 9 short cross veins carrying stout spines used to produce the female acoustic response (similar as shown in Heller et al. 1997); more distally small cross veins and even longitudinal veins with many 


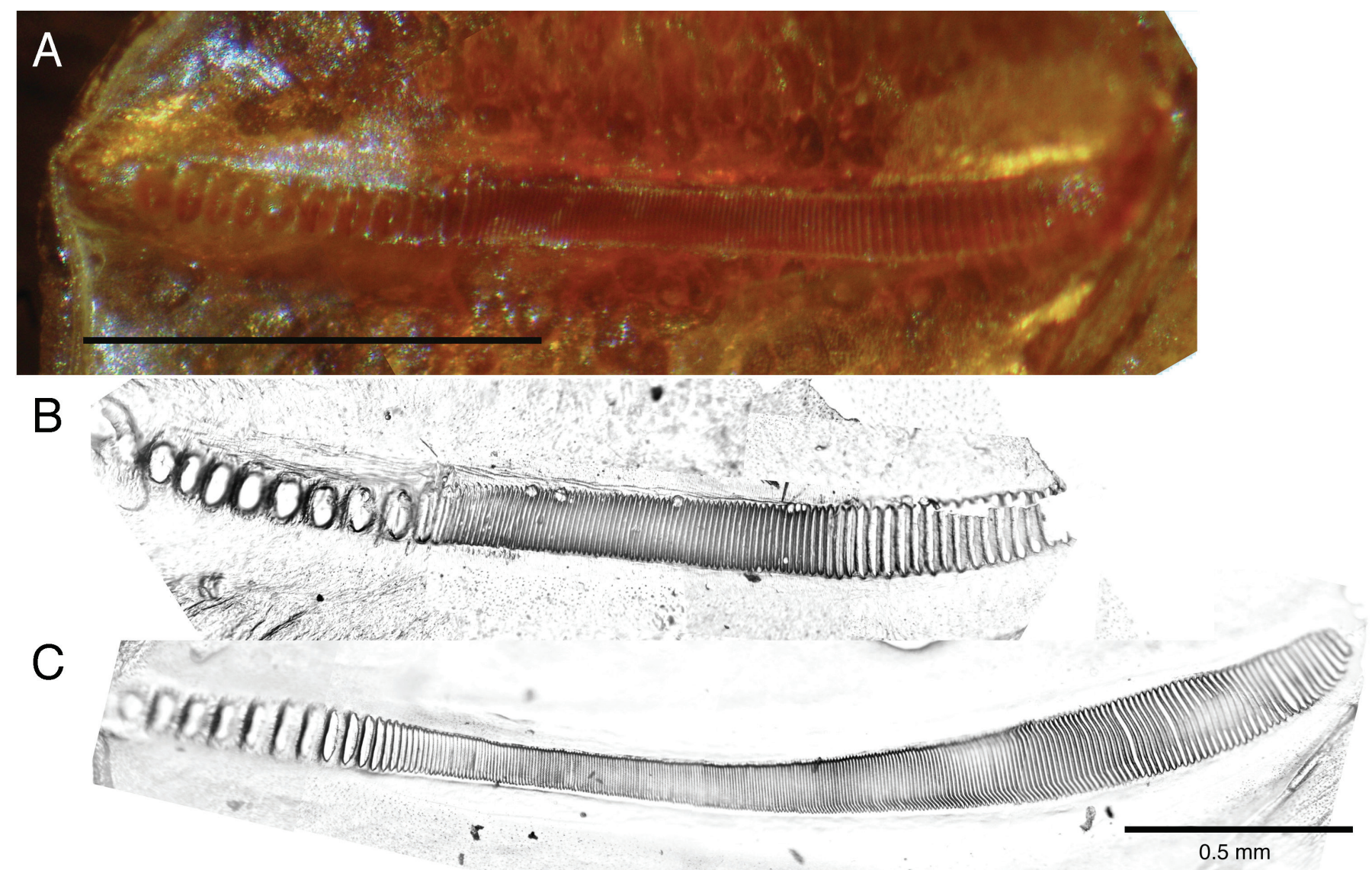

Figure 3. Stridulatory file of E. diuturna sp. n. and E. fulva (articulation of tegmen to the right). A. File of E. diuturna sp. n. on the underside of left male tegmen. Scale $1 \mathrm{~mm}$. B-C. Replica of the file of B. E. diuturna sp. n. in comparison to that of C. E. fulva.

Table 1. Proportions of distal and basal part and number of teeth in stridulatory file in Ectadia species.

\begin{tabular}{|c|c|c|c|c|c|}
\hline Species & Length of distal part of file & Number of teeth in distal part & Length of basal part of file & $\begin{array}{c}\text { Approximate number of teeth in } \\
\text { basal part }\end{array}$ & \\
\hline angusta & $1 / 4$ & $2^{*}$ & $3 / 4$ & $>80^{*}$ & Gorochov 2009 \\
\hline fulva & $1 / 6$ & 10 & $5 / 6$ & 250 & this paper \\
\hline mistshenkoi & $1 / 5$ & $2 *(8)$ & $4 / 5$ & $>110^{*}$ & Gorochov 2009 \\
\hline obsolescens & $1 / 4$ & $1-4$ & $3 / 4$ & $120-125$ & Liu et al. 2004 \\
\hline
\end{tabular}

* additional information by Gorochov in litt.

slender spines, probably used to prevent accidental wing opening. In left tegmen, posterior edge in basal part scraper-like in-curved. Supra-anal plate triangular; cerci rather short, conical. Ovipositor fairly broad and short, upcurved, both margins at tip denticulate (Fig. 9). Subgenital plate triangular, apex obtusely rounded.

Color.- Green except a white mid-line on pronotum and dorsal edges of tegmina (Fig. 5B).

Egg. - Thin, flattened, ovoid, typical phaneropterine shape.

Measurements (length in mm). - Body: male 14-20, female 17-22; pronotum: male 3.7-4.8, female 3.9-4.2; tegmen: male 26.7-31, female 22-25.3; tegmen width (greatest): male 5.1-6.5, female 4.9-5.1; hind wing: male 33-38; female 26-29.4; post femur: male 20.9-24, female 20.5-23.4; length of ovipositor: 6.5-8.1; width of ovipositor 1.9-2.1, length of egg 4.7-4.8; width of egg 1.6-1.8 ( $\mathrm{n}=12$ males, 6 females, partly dried, partly in ethanol).

Song. - Time-amplitude-pattern. In Ectadia diuturna sp. n. one song unit typically lasted about 30 to $60 \mathrm{~s}$ (all data for $25^{\circ} \mathrm{C}$ except otherwise mentioned; up to $80 \mathrm{~s}$ in the field at $18^{\circ} \mathrm{C}$ ). It was followed by the next unit after a silent interval as short as some seconds, but also as long as some minutes. The shortest intervals were observed when males and females were in acoustical contact. Each unit contained four phrases each of which consisted of 


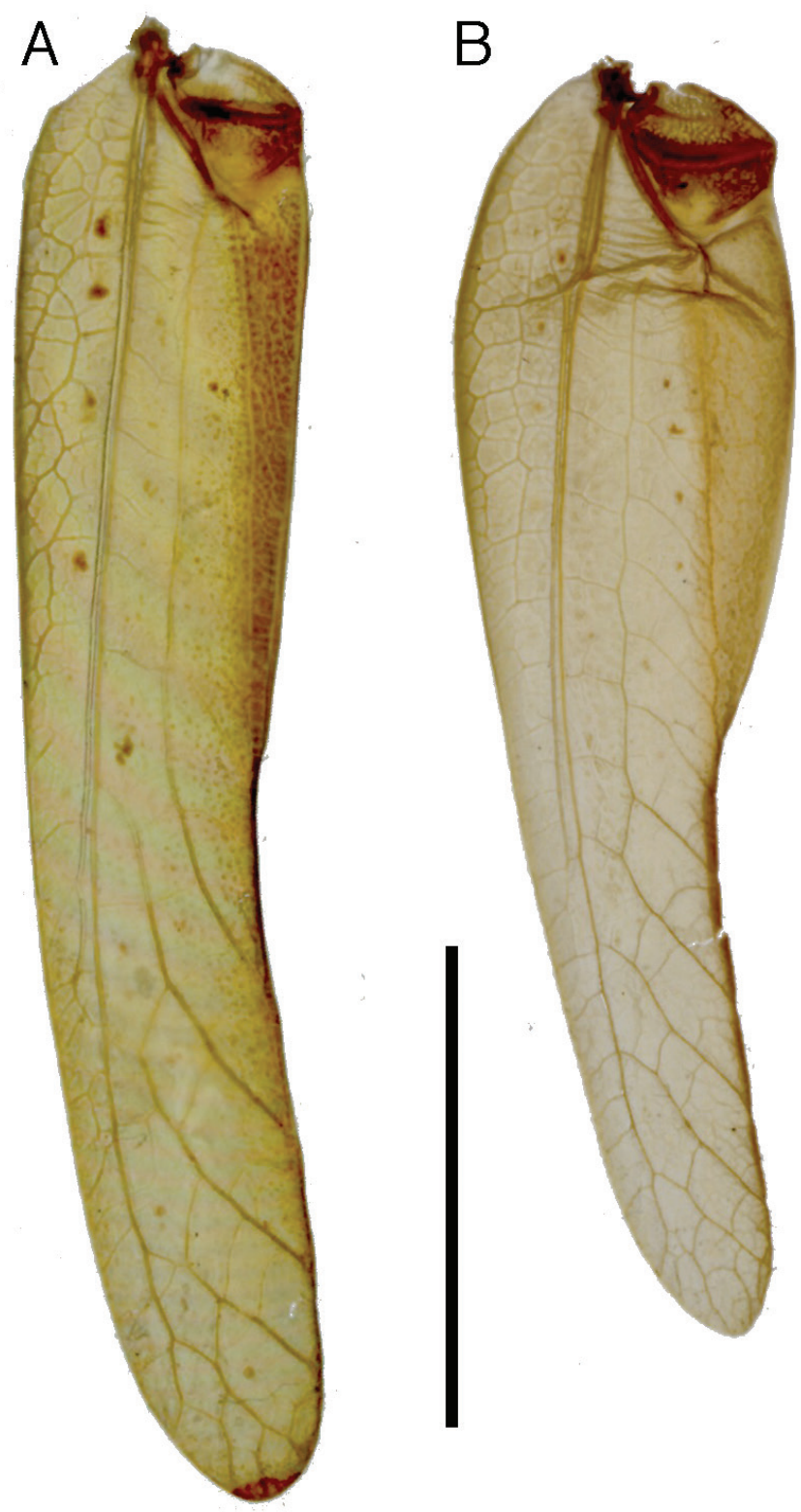

Figure 4. Transmitted light scan of left tegmina. A. Ectadia diuturna sp. n., B. E. fulva (the fold in the basal part is an artifact resulting from the strong curvature of the tegmen). Scale $10 \mathrm{~mm}$. a different combination of micro- and macrosyllables. A simple and clear example is shown in Fig. 10A. However, often the different phrases were connected by transitional phrases. A song unit started with a series of tick-like microsyllables, separated by intervals of about 150 ms (phrase A; see Fig. 11 for details). Sometimes the intervals between the ticks were larger and more irregular. Between these loud syllables (occasionally?) short and soft sounds were observed. At the end of a phrase typically two tick sounds followed each other quite closely (10 ms interval) a few times. Such phrases were also heard isolated outside complete song units, possibly representing unsuccessful attempts to start a song unit. After this phrase a series of macrosyllables followed (phrase B), in which always two types of impulse groups alternated, a long series (ca. 70 impulses; duration $120 \mathrm{~ms}$ ), sometimes split into two or more by one or several unusually large intervals, and a short series (ca. 55 densely packed impulses; duration 30-40 ms). Both groups differed distinctly in carrier frequency (see below). In amplitude, this phrase was always lower than the loud phrase A. Its duration was the most variable of all phrases, from nearly missing up to ten seconds. Phrase C consisted of a long series of stereotypic elements (period about $500 \mathrm{~ms}$ ), each containing two pairs of impulse groups as seen in phrase B. These pairs were separated from the next pair by an interval of about $200 \mathrm{~ms}$. During this interval one (or two) loud microsyllables were produced and additionally a series of softer isolated impulses. While in Fig. 10 an abrupt change from phrase $\mathrm{B}$ to $\mathrm{C}$ can be seen, in many other recordings there is a long transition with phrase $\mathrm{C}$ elements appearing more and more frequently (see e.g. Fig. 12). Phrase D finally consisted of several repetitions of the impulse series from phrase $\mathrm{C}$ (period about $400 \mathrm{~ms}$ ) without macrosyllables.

The females responded near the end of a song unit (Fig. 12). They answered mostly not only once, but several to many times (1-25 responses per song unit). The responses occurred nearly always during phrase $\mathrm{D}$, and often also additionally at the end of phrase C. Very rarely they were heard during phrase A, in this case the females possibly assuming a late phrase $\mathrm{D}$ from the previous song unit. In many phaneropterine species, the females respond with a species-specific delay after the male song or some parts of it (e.g. Heller and Helversen 1986). This is probably also the case in E. diuturna sp. n., but the response delay is difficult to measure exactly, because often several possible trigger events are closely together, and the response consists of several loud impulses distributed over more than $100 \mathrm{~ms}$. The delay is obvious in the range of 150-250 ms. In any case, often very soft impulses (more than 20

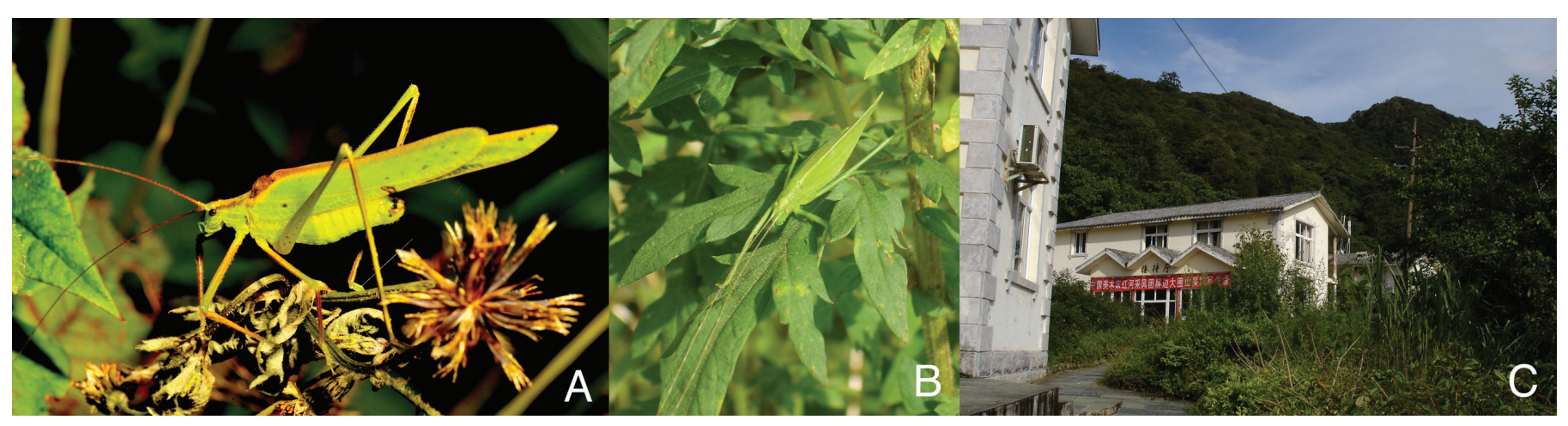

Figure 5. Habitus and habitat of E. diuturna sp. n. A. male (photo by Guoqing Ma), B. female, C. habitat at type locality. The photo of the male is shown under E. fulva in Kang et al. (2014). 


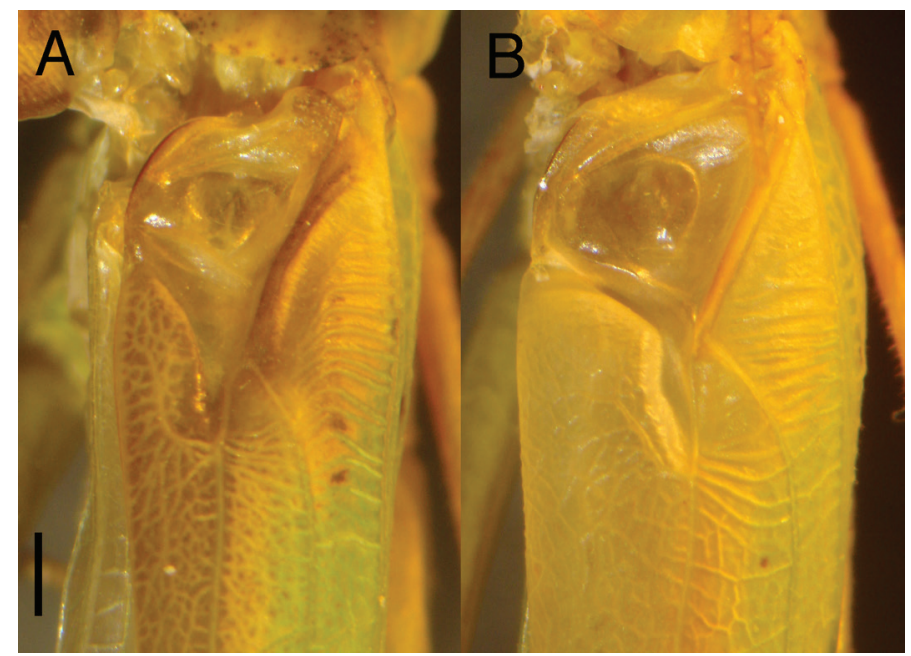

Figure 6. Stridulatory area with mirror at base of right tegmen. A. E. diuturna sp. n., B. E. fulva. Scale $1 \mathrm{~mm}$.

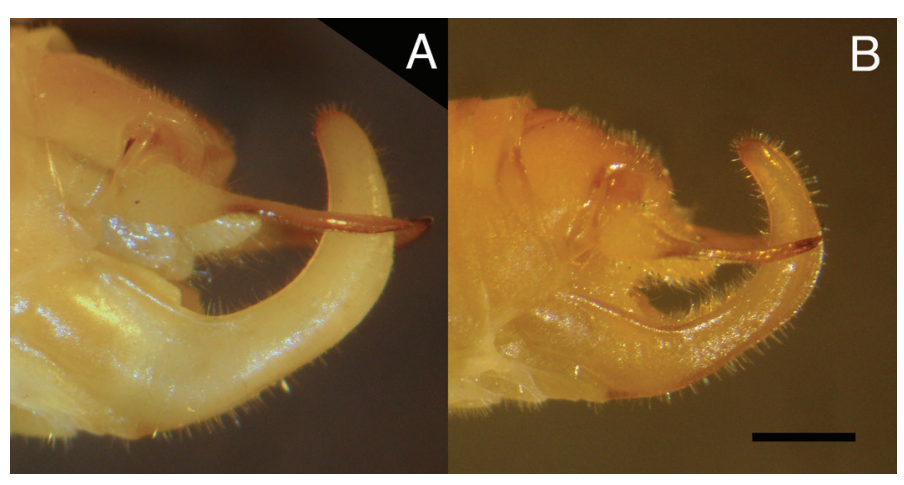

Figure 7. Lateral view of male subgenital plate. A. E. diuturna sp. n., B. E. fulva. Scale $1 \mathrm{~mm}$.

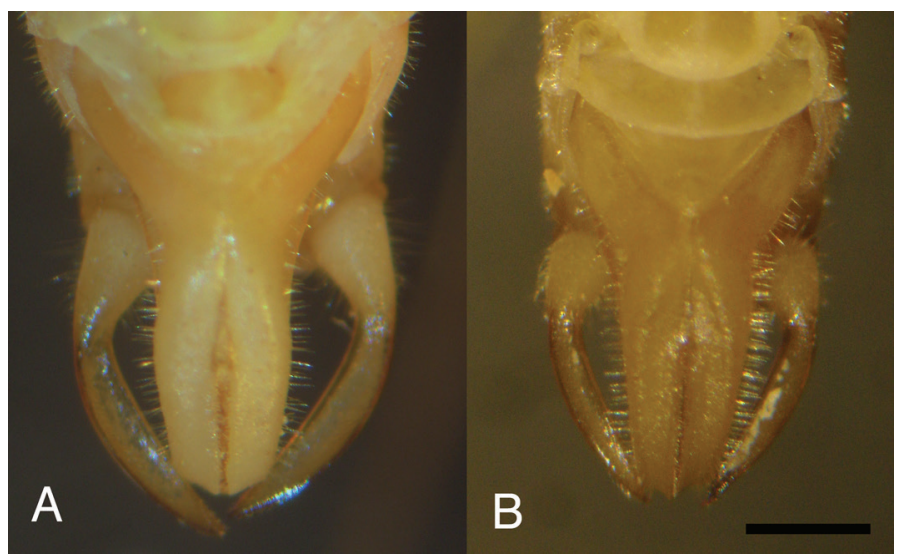

Figure 8. Ventral view of male subgenital plate. A. E. diuturna sp. n., B. E. fulva. Scale $1 \mathrm{~mm}$.

$\mathrm{dB}$ softer than the main response) were observed that occurred much faster (70-80 ms) than the loud impulses.

Carrier frequency.- During one song unit, parts with quite different spectral composition were observed. The short, tick-like elements

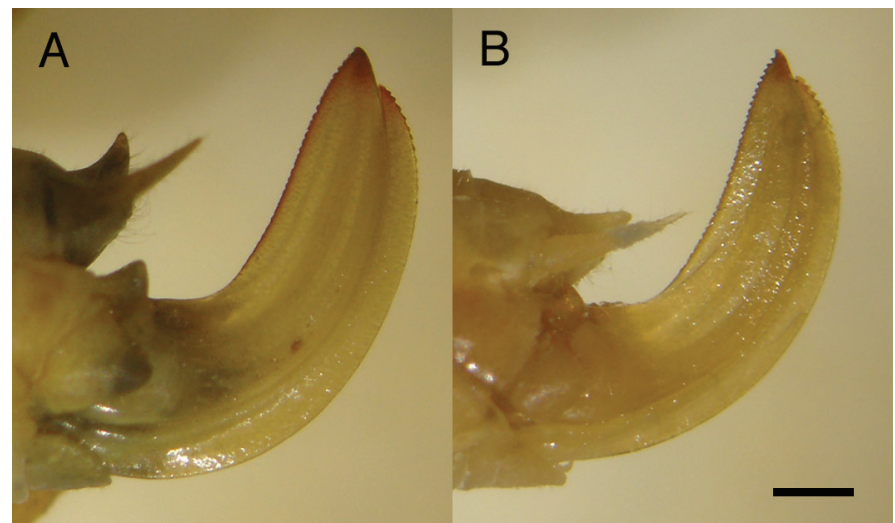

Figure 9. Lateral view of female ovipositor. A. E. diuturna sp. n., B. E. fulva. Scale $1 \mathrm{~mm}$.

of which phase A and D consisted and which occurred also in phase $C$, had always a quite similar spectrum. Its peak was situated at about $20 \mathrm{kHz}$, in the lower half with strong components starting abruptly at about $5 \mathrm{kHz}$, in the higher half continuously decreasing in power until $40 \mathrm{kHz}$ (Fig. 13). Also the softer and shorter impulse groups found in phase $\mathrm{B}$ and $\mathrm{C}$ were similar to this pattern presenting a relatively narrow peak at $20 \mathrm{kHz}$ and a side-peak at 40 $\mathrm{kHz}$. However, the longer and often louder impulse groups from phase B and C differed distinctly. Their spectrum contained two clearly separated peaks. Besides a high and narrow peak at $10 \mathrm{kHz}$ it showed a broad maximum at $60 \mathrm{kHz}$ (Fig. 13). These impulse groups alternated with the shorter and softer impulse groups (see fig. 5 in Heller et al. 2015). The female response had its maximum between 10 and $20 \mathrm{kHz}$ (recorded in audible range only).

Chromosomes. - The analyzed species is characterized by a male chromosome number $2 \mathrm{n}=29$ and sex determination system X0. All chromosomes are acrocentric and the $\mathrm{X}$ chromosome is the largest element in the set. C-banding of mitotic metaphase revealed constitutive heterochromatin blocks (thin C-bands) in the paracentromeric region in most chromosomal elements, with the exception of one small pair of autosomes (thick C-bands). Constitutive heterochromatin polymorphism involving telomeric $\mathrm{C}$ bands was located in the first-sized pair (Fig. 14A). The observed rDNA-FISH signal on this largest pair, similar to C-bands, varied in size, suggesting the occurrence of polymorphism in copy number of rDNA sequences (Fig. 14B).

Habitat. - Common in low bushes around buildings (Fig. 5C).

Etymology.- The name of the new species refers to its long lasting song: diuturna. Latin adjective, meaning long lasting

Distribution. - Known only from Yunnan, China.

\section{Ectadia fulva Brunner von Wattenwyl, 1893}

Fig. 15 morphology, Figs 16-17 song

Material examined.-For the behavioral studies four males and three females (out of series of nine each) were used, all offspring from animals from Thailand, Chiang Mai, Doi SuthepPui, $18^{\circ} 48^{\prime} \mathrm{N}, 98^{\circ} 55^{\prime} \mathrm{E}, 1100-1150 \mathrm{~m}$ a.s.l., 13.04.1995, ex ovo, bred in lab., leg. S. Ingrisch. Stridulatory files in six males, 


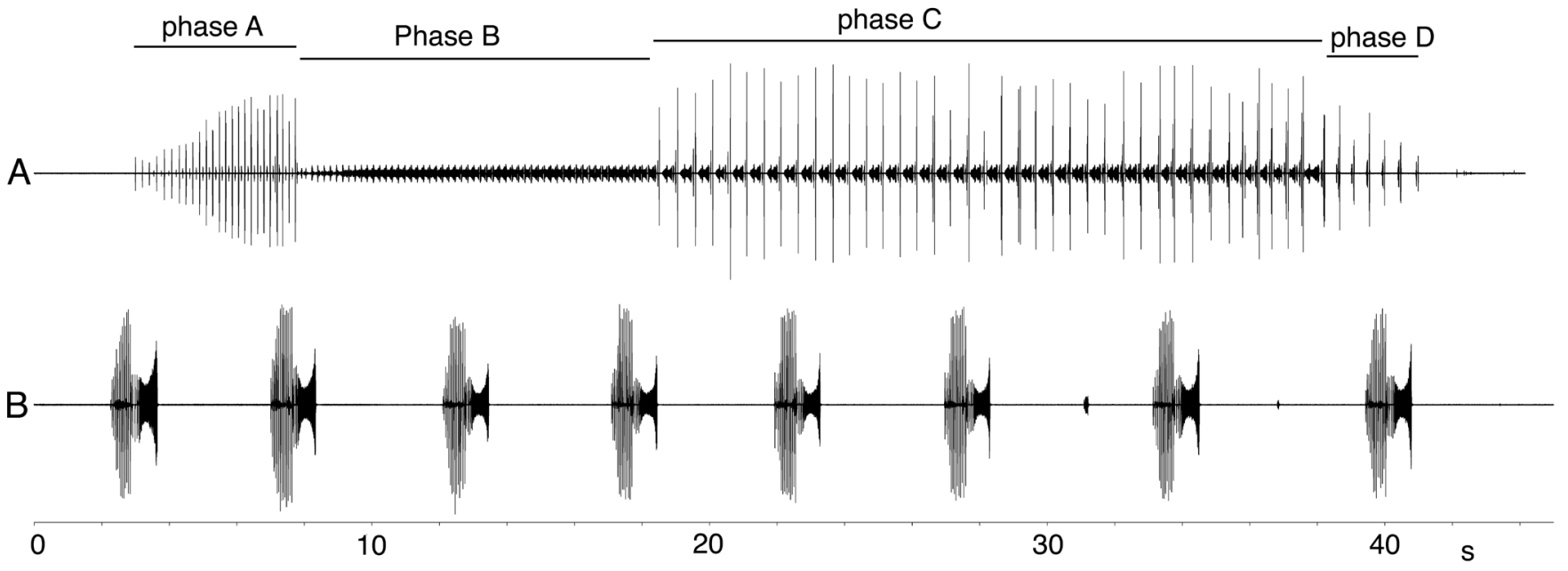

Figure 10. Oscillograms of male calling songs, comparative overview. A. E diuturna sp. n., B. E fulva, In A, the different phases of one song unit are indicated.
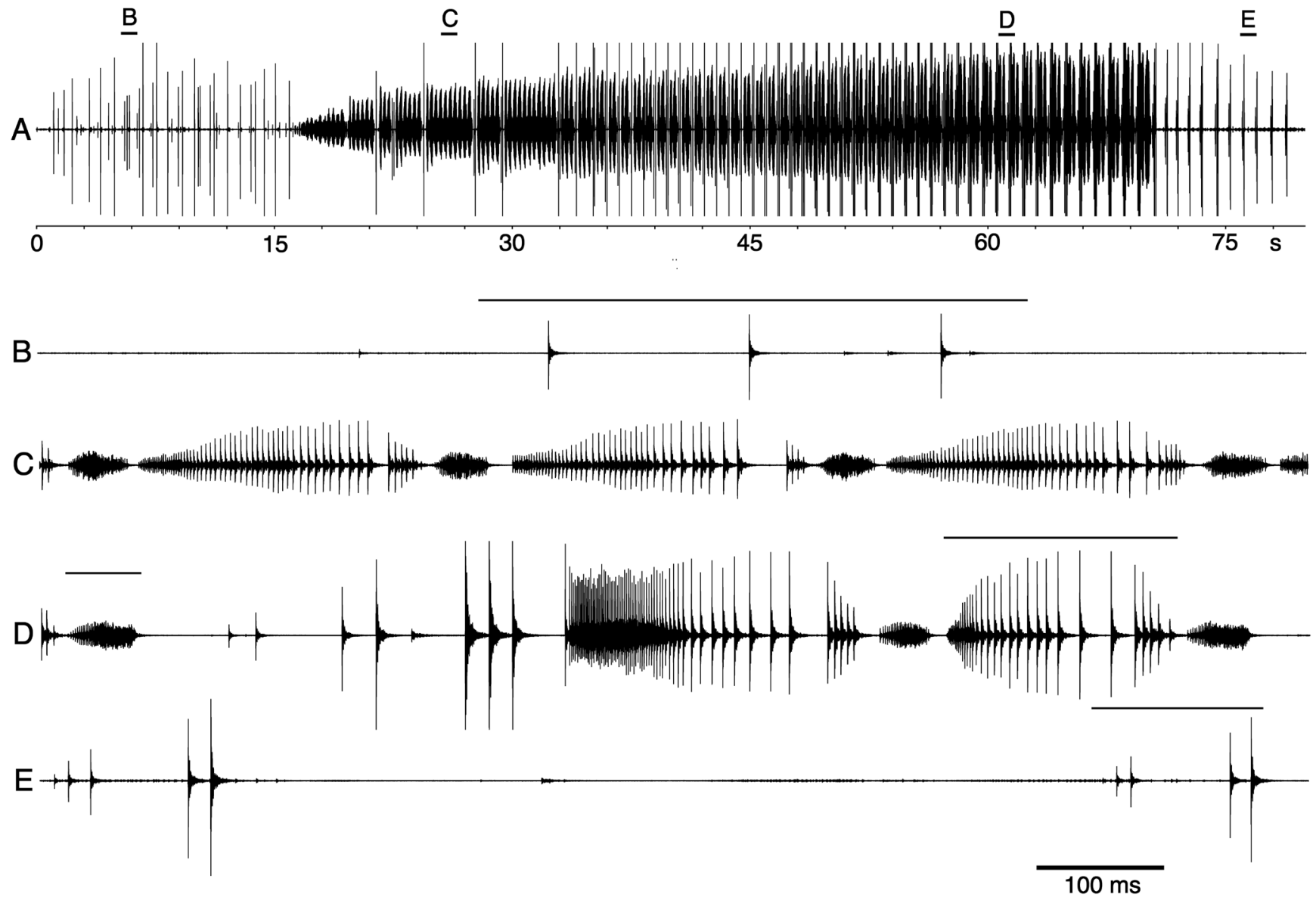

Figure 11. Oscillograms of male calling song of E. diuturna sp. n. A. Overview with indication of the origin of the details (B-E). In B, $\mathrm{D}$ and $\mathrm{E}$. the origin of the spectra shown in Fig. 12 is indicated.

China, Yunnan Province, Jinping County, Fenshuiling National Nature Reserve, $22.88178768^{\circ} \mathrm{E}, 103.23377388^{\circ} \mathrm{N}$, August 2012.
Description. - The species has been sufficiently redescribed by Liu et al. 2004. It may be added that the fore wings of the male are vaulted, bulging laterally in proximal half of tegmen 


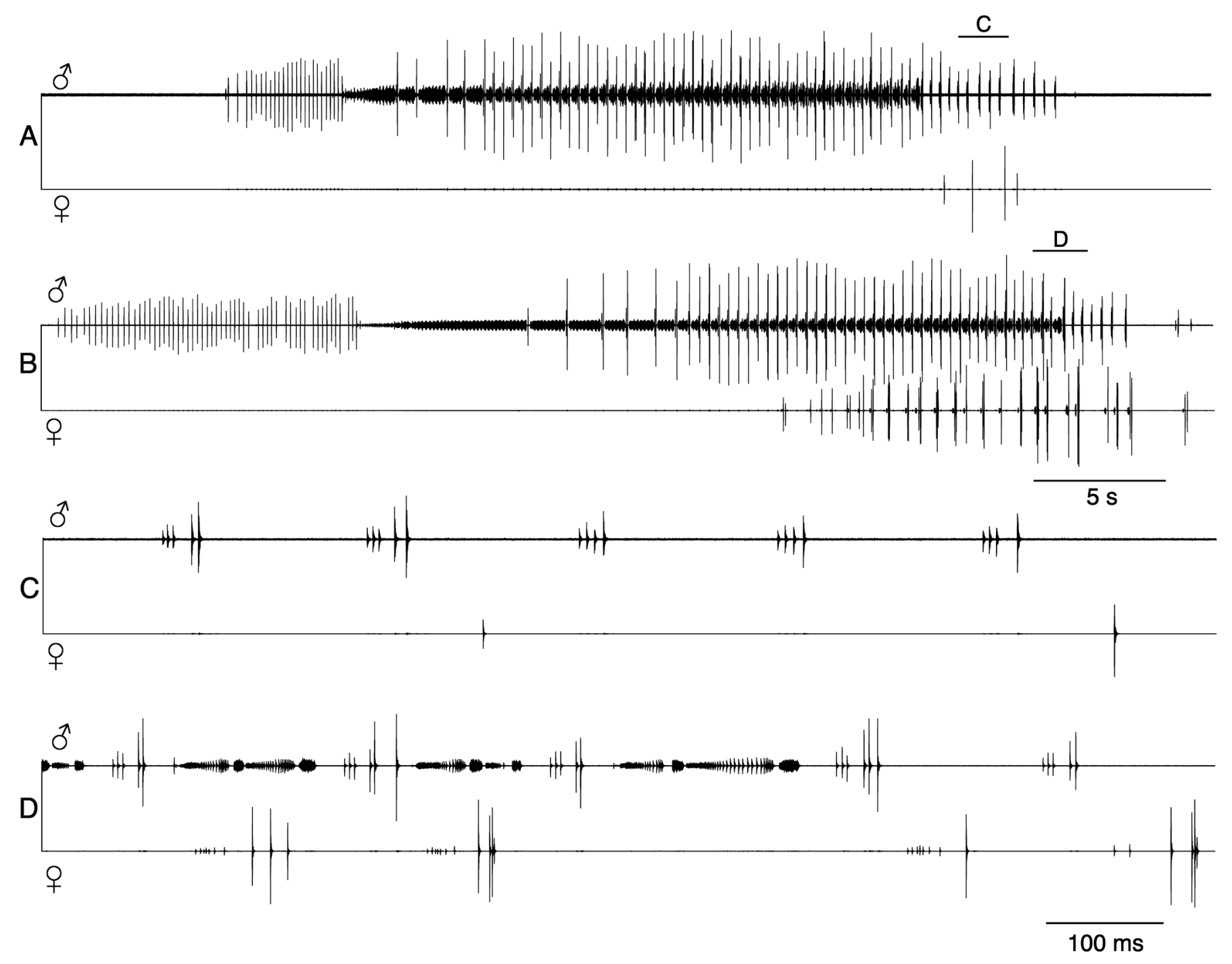

Figure 12. Oscillograms of male calling song and female response of E diuturna sp. n., recorded simultaneously. A, B. Overviews with indication of the origin of the details (C-D).

length, flat with rounded tip thereafter; those of the female are shortened with acute tip. In both sexes the hind wings surpass the fore wings. The species shows a green-brown color polymorphism in both sexes. Of the specimens collected in the field, two males and two females were green and two males and one female brown. The brown color is of lighter shade in females (more ochreous) than in males (medium brown with dark pattern). In the offspring of a green female bred in lab, 19 males and 12 females became green, four males and nine females brown. Body, legs, fore wings and the projecting part of the hind wings were either all green or all brown, in two females pale yellowish brown. The broad dorsal field of the male tegmen including the stridulatory area was always dark brown in both color morphs while the narrow dorsal field of the female tegmen was yellow in green females or pale brown bordered by a dark brown line in brown females. In resting position, $E$. fulva sits with the antennae and the fore legs stretched anteriorly in the body axis, the mid and the hind legs are stretched oblique posteriorly, while the abdomen and the wings are pointing dorso-posteriorly. That behavior resembles the situation in Ducetia (e.g. D. japonica) or Elimaea species.

Song.- Time-amplitude-pattern. The male calling song consisted of song units each lasting about $1.5 \mathrm{~s}$ repeated after an interval of about $4 \mathrm{~s}$ (Fig. 16A). Each was made of a series of microsyllables (about 15), repeated with $20 \mathrm{~Hz}$, followed by a long series of impulses with decreasing intervals. This song unit is produced by opening the tegmina very widely, then closing and opening them several times only in part, resulting in the microsyllables. The microsyllables are not tick-like sounds as in E. diuturna sp. n., but consist of compact series each with a few impulses. Then the male closed the tegmina completely and very slowly. The contact of the scraper with the fine basal part of the file produced a long series of heavily damped impulses (Fig. 16; see also fig. 7 in Heller et al. 2014). 

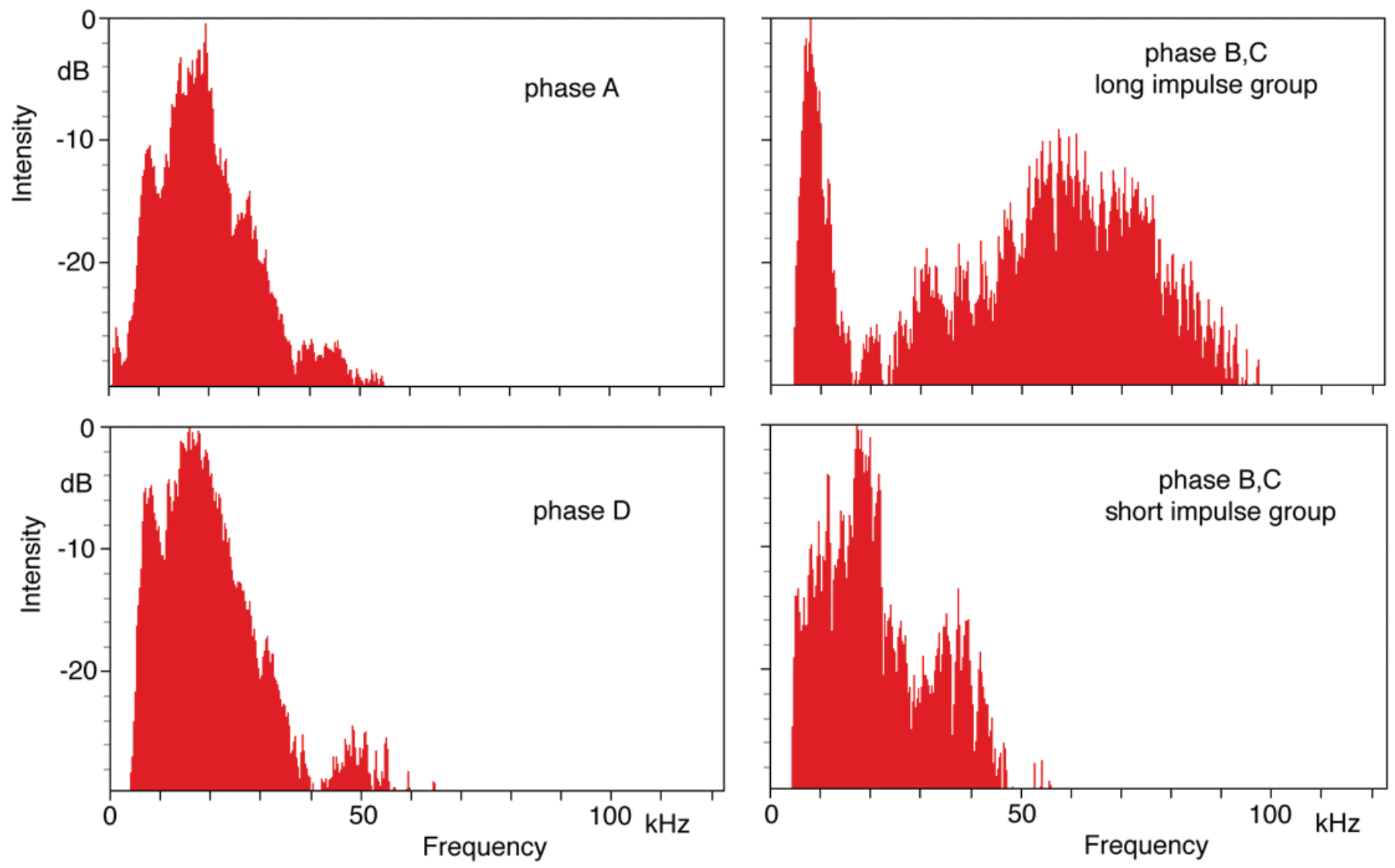

Figure 13. Power spectra of different parts of the calling song of E. diuturna sp. n.
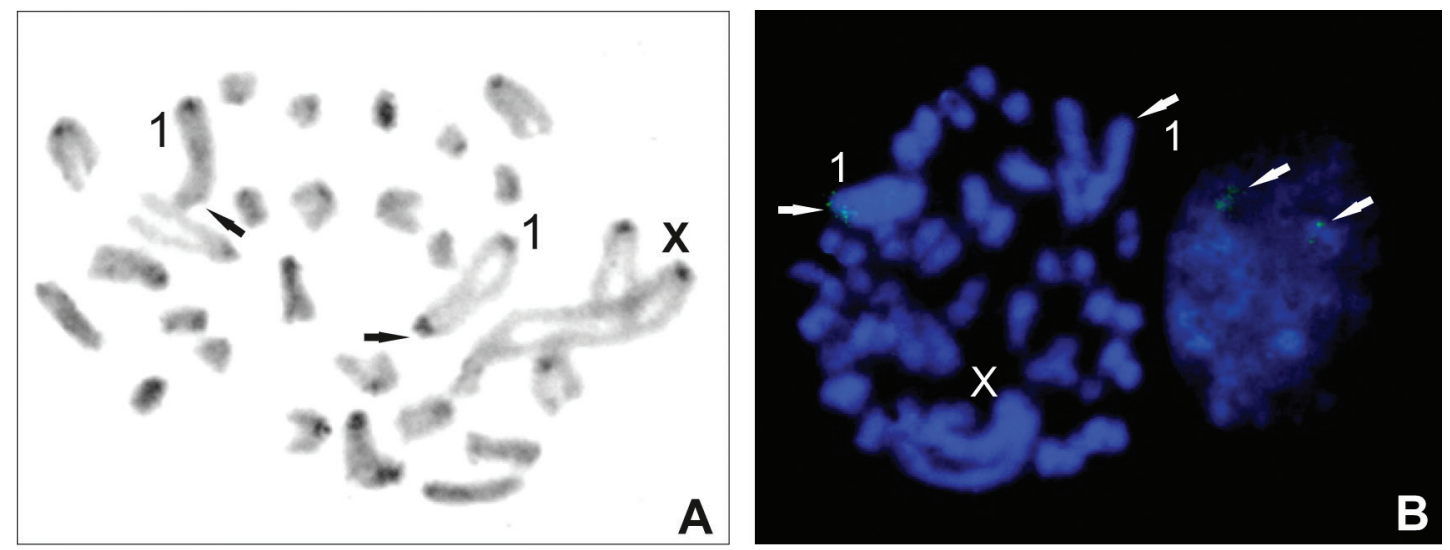

Figure 14. Male chromosomes of Ectadia diuturna sp. n. A. C-banded metaphase; B. FISH with $18 \mathrm{~S}$ rDNA (green) probe in metaphase/ anaphase (A - the left) and prometaphase (B - the right). Arrows indicate telomeric located C-bands (A) and cluster of 18S rDNA (B) in the heteromorphic large-sized chromosomes (marked with "1"); X, sex chromosome.

The female responded immediately after the end of the male impulse series (Fig. 16), typically with one or a few impulses, occasionally with one or a small series up to a few hundred ms later in addition. Sometimes responses were observed even before the male series had ended.
Carrier frequency. - Both parts of the song unit had a quite similar spectral composition with two peaks (Fig. 17). Besides a narrow low-frequent peak around $10 \mathrm{kHz}$ there was a broad maximum at about 50-60 kHz. The female response showed a peak at $20 \mathrm{kHz}$, in width and placement intermediate between the two male peaks. 


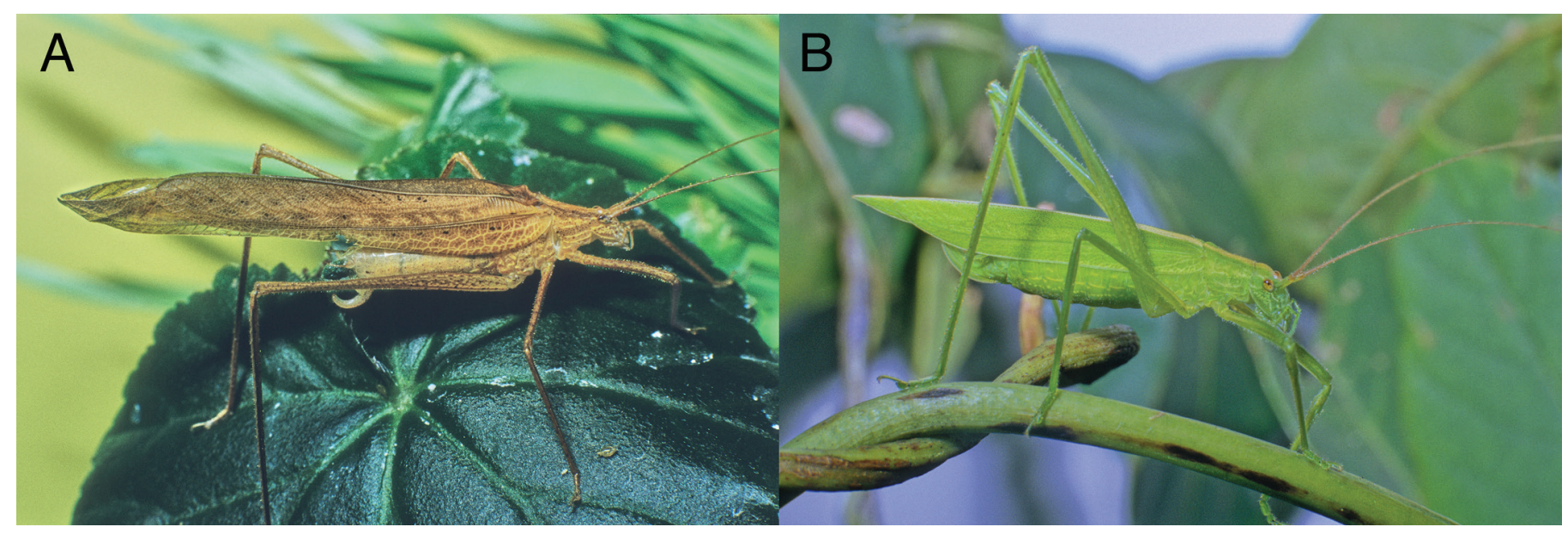

Figure 15. Habitus of Ectadia fulva. A. male, B. female.
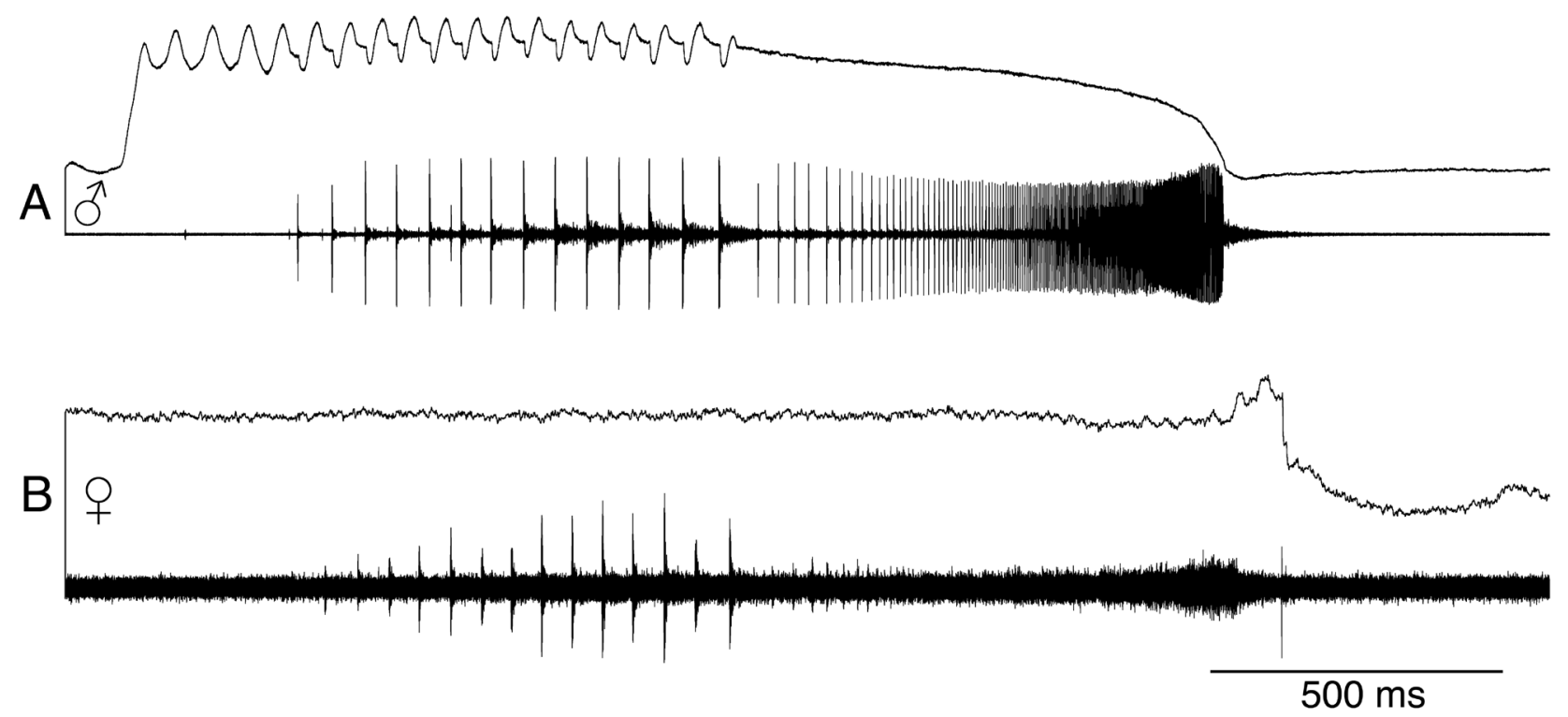

Figure 16. Male calling song A. and female response B. of Ectadia fulva. Oscillograms of stridulatory movement and song [synchronous registration of left tegmen movement and sound (upper line: upward deflection represents opening, downward closing; lower line: sound)]. Male and female were recorded separately.
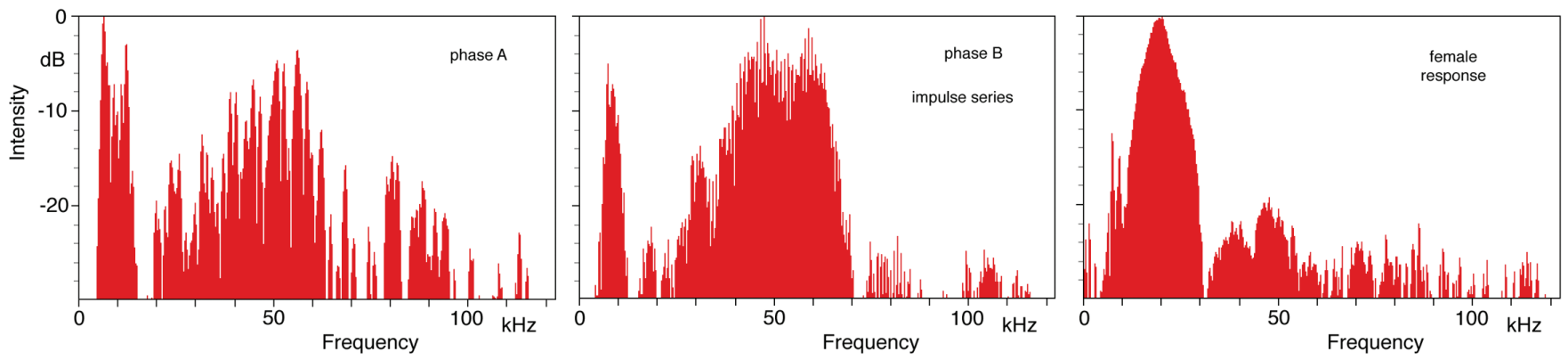

Figure 17. Power spectra of different parts of the male calling song and of the female response of $E$. fulva. 


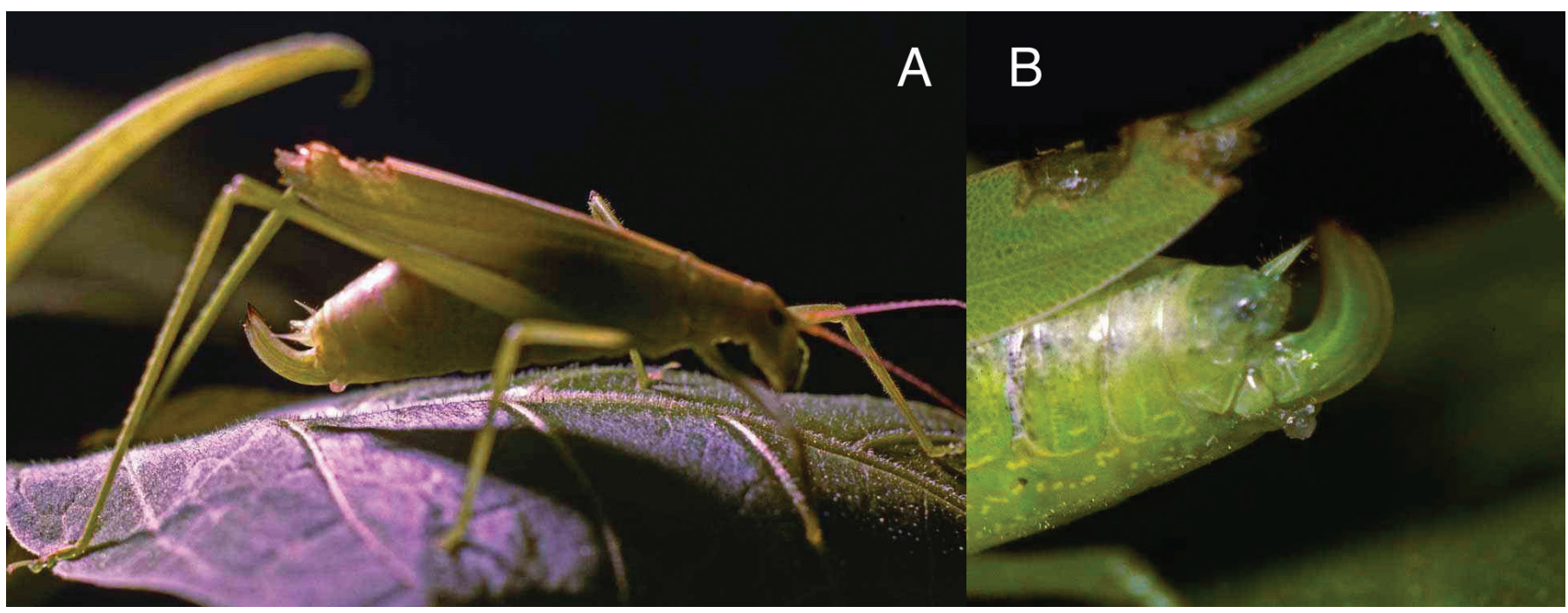

Figure 18. Female Ectadia fulva with spermatophore. A. overview, B. detail.

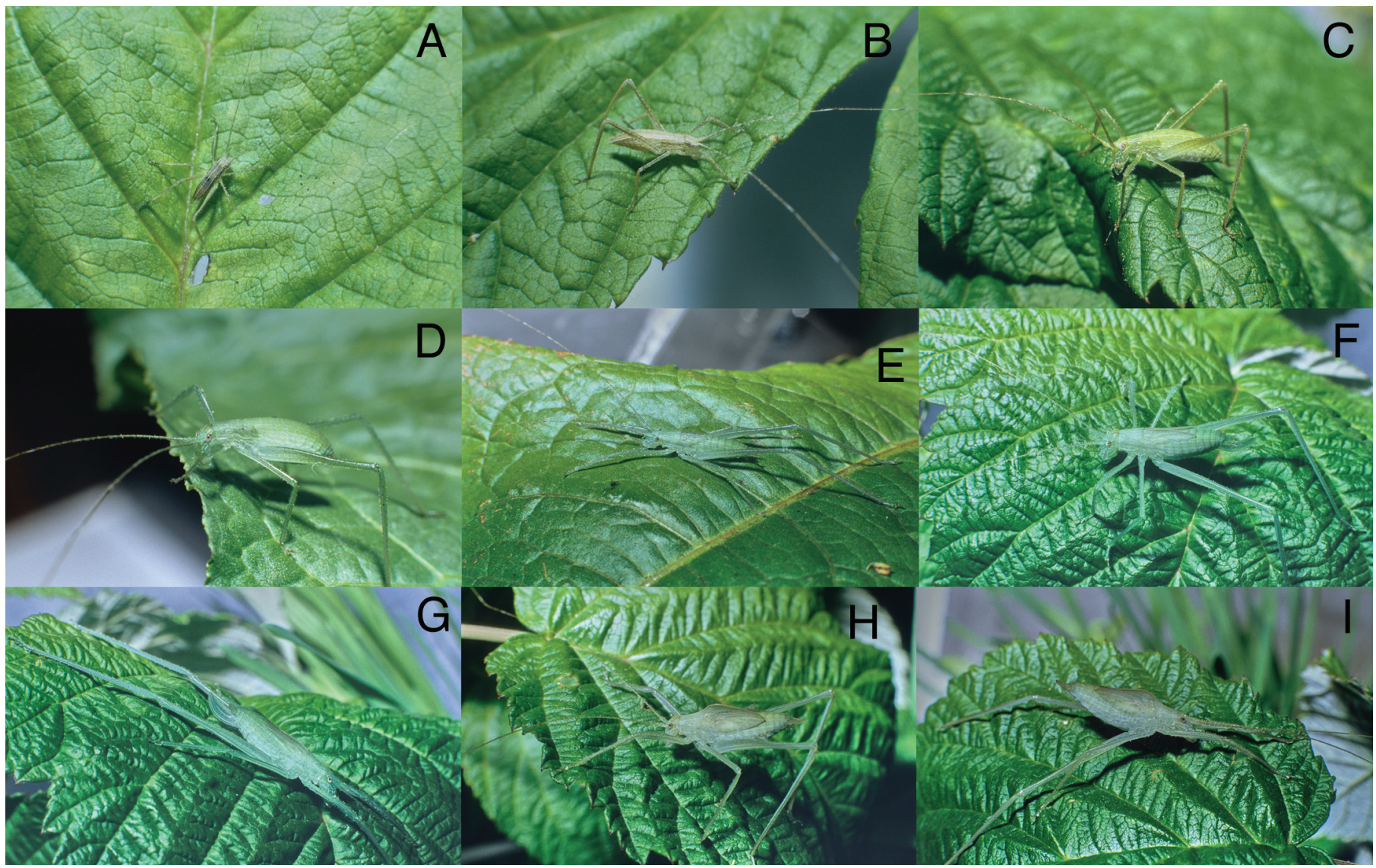

Figure 19. Nymphs of Ectadia fulva. A. First stage, B. second stage, C. third stage, D. $4^{\text {th }}$ stage, E. $5^{\text {th }}$ stage, male, F. $5^{\text {th }}$ stage, female, G. $6^{\text {th }}$ stage, female, H, I. $6^{\text {th }}$ stage, male.

Besides the acoustical signals soundless vibratory body movements were observed in both sexes.

Mating. - In eight tests, a male (mean body mass $199 \pm 16 \mathrm{mg} ; \mathrm{n}=7$ ) and a female (mean body mass $626 \pm 71 \mathrm{mg} ; \mathrm{n}=6$ ) were placed together for mating. Four couples mated with the males transferring only very small spermatophores $(1.3 \pm 0.6 \mathrm{mg}$; no data on mating duration available; Fig. 18). Obviously the spermatophores consisted only from a pair of ampullas without spermatophylax.

Nymphs. - Postembryonic development occured over six nymphal instars as in many other Phaneropterinae (Fig. 19). Development 
from hatching to adult moult took $52-68$ days at $20-23^{\circ} \mathrm{C}$ (Ingrisch 1998). Nymphs can be green or light brown. First instars appear green colored.

Distribution.- See Fig. 1.

\section{Discussion}

Since the revision by Liu et al. (2004) the genus Ectadia is known for its diversity in male stridulatory files. Adding two more species, Gorochov (2009) again emphasizes characters connected to sound production, situated in the mirror area and the stridulatory file. However, until now only the song of E. fulva was known (Ingrisch 1998, Heller et al. 2015). E. diuturna sp. n. presents a song quite different in structure to that of E. fulva. The song of $E$. fulva consists of complicated but relatively short song units (less than $2 \mathrm{~s}$ ) produced during opening and closing of the tegmina once completely, while the song units of E. diuturna sp. n. are very long lasting (more than $30 \mathrm{~s}$ ) made by many movement cycles of the tegmina. The song of E. diuturna sp. n. thus resembles that of Ducetia japonica (Heller et al. 2017). Also the stridulatory files both in the Ducetia japonica group and Ectadia contain two parts with different structures. The genus Ducetia is phylogenetically probably close to Elimaeini where Ectadia also belongs to (Gorochov 2009, Liu in prep.). However, Ectadia diuturna sp. $\mathrm{n}$. and Ducetia japonica differ in a bioacoustically important point. During the long and complicated songs of Ducetia, no significant changes in spectrum were observed (Heller et al. 2017). While this is also true for E. fulva, in the song of E. diuturna sp. n. elements with three different spectra were recorded.

How may these different spectra be produced? From the spectral similarity between E. fulva and the long impulse group in $E$. diuturna sp. n., one can assume that this two-peak spectrum represents the typical vibration mode of the tegmina when excited during closing. A derived spectrum may result if the teeth are contacted during the opening movement. In several tettigonioid species the sounds produced during opening of the wings have different spectra than during closing (e.g. Metrioptera spp. Heller 1988, Skejo et al. 2015; Lithodusa helverseni Heller and Korsunovskaja 2009; Saga spp. Lemonnier-Darcemont et al. 2016, and with good reason assumed also for Xiphelimum amplipennis by Morris et al. 2016). This argument may apply for the short impulse group in E. diuturna sp. n. The different spectrum of the tick-like sounds may possibly result from the contact of large teeth situated anally near to the outer margin of the tegmen.

Do the different frequencies have any biologically important function? There is no simple answer. The argument that broadbanded songs or songs with different frequencies can give some information about the distance to a signaller (see Morris et al. 2016) is certainly correct. But since the spectrum of the female response - assumed to be similar in E. diuturna sp. n. to that of E. fulva also has its peak at $20 \mathrm{kHz}$ like the tick-like sounds and the short impulse group, one has to analyse carefully what happens if rivals hear a male song together with a female response. Communication by duetting is always susceptible to eavesdropping. Possibly the mixture of signals with different spectra make this kind of signal exploitation more difficult. Males of the African phaneropterine Gonatoxia helleri seem even to imitate the spectrum of the female response to disturb eavesdropping rivals (Heller and Hemp in prep.).

Surprisingly, the species which deviates in file morphology most widely from all others - Ectadia fulva - has by far the largest geographic range. One reason could be that this species seems to be adapted to relatively low altitudes. It was found between 250 and 1300 m a.s.l. (Ingrisch 1998, Liu et al. 2004, Gorochov 2009), while E. sinuata, E. angusta and E. diuturna occur at $1600 \mathrm{~m}$ a.s.l. and much above (Liu et al. 2004, Gorochov 2009, this paper). Only in Vietnamese Tam Dao at 800-1000 m a.s.l. - relatively high for E. fulva - does this species occur together with Ectadia mistshenkoi. A similar partial overlap may exist with E. obsolescens (650-1600 $\mathrm{m}$ a.s.1.). Possibly most other Ectadia species are restricted to (isolated) mountains, although for some species the altitude of their occurrence is not known. So the differences in stridulatory organs are not easily explained by interspecific interactions except assuming much wider ranges than today during the ice ages.

Concerning chromosome evolution, the data presented here are the first available for the genus Ectadia. The basic model karyotype of Phaneropterinae, present also in most tettigoniids, consists of 31 (male) with the X0 (male) sex determination system (for a review see Warchałowska-Śliwa 1998). In Ectadia, similarly to phaneropterids in another genus of the tribe Elimaeini, Elimaea, and in the related Ducetia, the ancestral chromosome number is reduced to $2 \mathrm{n}=29$ (X0), including one tandem fusion between two pairs of autosomes, all chromosomes being acrocentric (e.g. Heller et al. 2017, Warchałowska-Śliwa et al. 2011). In Ectadia diuturna, the pattern of heterochromatin distribution has revealed size heteromorphism of C- bands and differential intensity of rDNA hybridization-signals between homologous chromosomes of long-sized pair. These differences suggest the occurrence of polymorphism in the number of copies of rDNA sequences as a result of amplification or loss through different mechanisms such as unequal meiotic crossing-over, homologous recombination, tandem duplication of ribosomal genes, or translocation rearrangements (e.g. Cabral-de-Mello et al. 2011). Similar heteromorphism has been observed in other bushcrickets (e.g. Warchałowska-Śliwa et al. 2013, Grzywacz et al. 2014).

\section{Acknowledgements}

Our thanks go to Susanne Randolf, Vienna, for the unsuccessful search for the holotype of E. pilosa, and to Andrei Gorochov, St. Petersburg, for information about the files of some Ectadia species. The study was partly funded by the National Natural Science Foundation of China (No. 31572308).

\section{References}

Bai JR, Shi FM (2014) Faunistic study of Tettigoniidae from Guangxi. http://www.docin.com/p-102143(2957)html [In Chinese]

Bey-Bienko GY (1962) Results of the Chinese-Soviet zoological-botanical expeditions to south-western China 1955-(1957) New or less known Tettigonioidea (Orthoptera) from Szechuan and Yunnan. Trudy Zoologitscheskogo Instituta Akad. Nauk SSSR [= Proc. Zool. Inst. Acad. Sci. USSR] 30: 110-138. [Russian]

Brunner von Wattenwyl C (1878) Monographie der Phaneropteriden. Brockhaus, Wien. 401pp., pls 1-8.

Brunner von Wattenwyl C (1893) Révision du système des orthoptères et description des espèces rapportées par M Leonardo Fea de Birmanie. Annali del Museo Civico di Storia Naturale 'Giacomo Doria', Genova 33: 1-230, pls 1-6. https://doi.org/10.5962/bhl.title.5121

Cabral-de-Mello DC, Martins C, Souza MJ, Moura RC (2011) Cytogenetic mapping of $5 \mathrm{~S}$ and $18 \mathrm{~S}$ rRNAs and $\mathrm{H} 3$ histone genes in four ancient Proscopiidae grasshopper species: contribution to understanding the evolutionary dynamics of multigene families. Cytogenetic and Genome Research 132: 89-93. https://doi.org/10.1159/00031(7476) 
Gorochov AV (2009) New and little known katydids of the tribe Elimaeini (Orthoptera, Tettigoniidae, Phaneropterinae). Proceedings of the Russian Entomological Society 80: 77-128.

Grzywacz B, Chobanov DP, Maryańska-Nadachowska A, Karamysheva TV, Heller K-G, Warchałowska-Śliwa E (2014) A comparative study of genome organization and inferences for the systematics of two large bushcricket genera of the tribe Barbitistini (Orthoptera: Tettigoniidae: Phaneropterinae). BMC Evolutionary Biology 14: 48. https://doi. org/10.1186/1471-2148-14-48

Grzywacz B, Maryańska-Nadachowska A, Chobanov DP, Karamysheva T, Warchałowska-Śliwa E (2011) Comparative analysis of the location of rDNA in the Palaearctic bushcricket genus Isophya (Orthoptera: Tettigoniidae: Phaneropterinae). European Journal of Entomology 108: 509-517. https://doi.org/10.14411/eje.2011.066

Heller K-G (1988) Bioakustik der europäischen Laubheuschrecken. Ökologie in Forschung und Anwendung 1. J Margraf, Weikersheim, 358 pp.

Heller K-G, Helversen D v. (1986) Acoustic communication in phaneropterid bushcrickets: species-specific delay of female stridulatory response and matching male sensory time window. Behavioral Ecology and Sociobiology 18: 189-198. https://doi.org/10.1007/ BF00290822

Heller K-G, Korsunovskaya O (2009) Systematics and bioacoustics of the genus Lithodusa (Orthoptera: Tettigoniidae) including the description of a new species from Turkey and comments on the classification of the Drymadusini. Journal of Orthoptera Research 18: 5-13. https:// doi.org/10.1665/034.018.0107

Heller K-G, Hemp C, Ingrisch S, Liu CX (2015) Acoustic communication in Phaneropterinae (Tettigonioidea) - a global review with some new data. Journal of Orthoptera Research 24: 7-18. https://doi. org/10.1665/034.024.0103

Heller K-G, Ingrisch S, Liu CX, Shi FM, Hemp C, Warchałowska-Śliwa E, Rentz DCF (2017) Complex songs and cryptic ethospecies: the case of the Ducetia japonica group (Orthoptera: Tettigonioidea: Phaneropteridae: Phaneropterinae). Zoological Journal of the Linnean Society zlw019. https://doi.org/10.1093/zoolinnean/zlw019

Heller K-G, Schul J, Ingrisch S (1997) Sex-specific differences in song frequency and hearing in some duetting bushcrickets (Orthoptera: Tettigonioidea: Phaneropteridae). ZACS - Zoology Analysis of Complex Systems 100: 110-118. https://doi.org/10.1007/BF00611248

Helversen O v., Elsner N (1977) The stridulatory movements of acridid grasshoppers recorded with an opto-electronic device. Journal of Comparative Physiology 122: 53-64.

Ingrisch S (1998) A review of the Elimaeini In Western Indonesia, Malay Peninsula and Thailand (Ensifera, Phaneropteridae). Tijdschrift voor Entomologie 141: 65-108. https://doi.org/10.1163/22119434-99900006

Kang L, Liu CX, Liu X (2014) Fauna Sinica Insecta. Vol. 57. Orthoptera Tettigoniidae Phaneropterinae. Science Press, Beijing.
Lemonnier-Darcemont M, Darcemont C, Heller K-G, Dutrillaux A-M, Dutrillaux B (2016) Saginae of Europa. Edition GEEM, Callian, France.

Li R, Kraft Nathan JB, Yang J, Wang Y (2015) A phylogenetically informed delineation of floristic regions within a biodiversity hotspot in Yunnan, China. Scientific Reports 5: 9396. https://doi.org/10.1038/srep09396

Liu CX, Kang L, Liu XW (2004) The genus Ectadia Brunner von Wattenwyl (Orthoptera: Tettigoniidae: Phaneropterinae), with descriptions of three new species from China. Raffles Bulletin of Zoology 52: 37-43.

Morgan K, O'loughlin SM, Chen B, Linton Y-M, Thongwat D, Somboon P, Fong MY, Butlin R, Verity R, Prakash A, Htun PT, Hlaing T, Nambanya S, Socheat D, Dinh TH, Walton C (2011) Comparative phylogeography reveals a shared impact of pleistocene environmental change in shaping genetic diversity within nine Anopheles mosquito species across the Indo-Burma biodiversity hotspot. Molecular Ecology 20: 4533-4549. https://doi.org/10.1111/j.1365-294X.2011.05268.x

Morris GK, Braun H, Wirkner CS (2016) Stridulation of the clear-wing meadow katydid Xiphelimum amplipennis, adaptive bandwidth. Bioacoustics 25: 225-251. https://doi.org/10.1080/09524622.2016.1138883

Ragge DR (1969) A revision of the African species of Pseudorhynchus Serville (Orthoptera: Tettigoniidae). Bulletin of the British Museum (Natural History), Entomology Series 23: 169-190. https://doi. org/10.5962/bhl.part.15133

Ragge DR, Reynolds WJ (1998) The songs of the grasshoppers and crickets of western Europe. Harley Books, Colchester, Essex. 591 pp.

Skejo J, Rebrina F, Tvrtkovic N, Gomboc S, Heller K-G (2015) More than a century old, Platycleis Kraussi case finally resolved (Tettigoniidae: Platycleidini). Zootaxa 3990: 497-524. https://doi.org/10.11646/ zootaxa.3990.4.2

Sumner AT (1972) A simple technique for demonstrating centromere heterochromatin. Experimental Cell Research 75: 304-306. https://doi. org/10.1016/0014-4827(72)90558-7

Tang CQ (2015) The Subtropical Vegetation of Southwestern China: Plant Distribution, Diversity and Ecology. Springer, New York et al. 363 pp.

Warchałowska-Śliwa E (1998) Karyotype characteristics of katydid orthopterans (Ensifera, Tettigoniidae) and remarks on their evolution at different taxonomic levels. Folia Biologica (Kraków) 46: 143-176.

Warchałowska-Śliwa E, Grzywacz B, Maryańska-Nadachowska A, Karamysheva T, Heller K-G, Lehmann AW, Lehmann GUC, Chobanov DP (2013) Molecular and classical chromosomal techniques reveal diversity in bushcricket genera of Barbitistini (Orthoptera). Genome 56: 667-676. https://doi.org/10.1139/gen-2013-0119

Warchałowska-Śliwa E, Maryańska-Nadachowska A, Grzywacz B, Karamysheva T, Lehmann AW, Lehmann GUC, Heller K-G (2011) Changes in the numbers of chromosomes and sex determination system in bushcrickets of the genus Odontura (Orthoptera, Tettigoniidae, Phaneropterinae). European Journal of Entomology 108: 183-195. https://doi. org/10.14411/eje.2011.025 